\title{
ZEARALENONE AND OCHRATOXIN A: ADSORPTION BY KAOLIN MODIFIED WITH SURFACTANT
}

\author{
Milica P. Spasojevićl, Aleksandra S. Daković ${ }^{* 1}$, George E. Rottinghaus ${ }^{2}$, \\ Ana S. Radosavljević-Mihajlovićl, Marija A. Marković ${ }^{1}$, Danina R. Krajišnik ${ }^{3}$ \\ ${ }^{1}$ Institute for Technology of Nuclear and Other Mineral Raw Materials, \\ Franche d' Epere 86, 11000 Belgrade, Serbia \\ ${ }^{2}$ Veterinary Medical Diagnostic Laboratory, College of Veterinary Medicine, \\ University of Missouri, Columbia, MO 65211, USA \\ ${ }^{3}$ Department of Pharmaceutical Technology and Cosmetology, University of \\ Belgrade, Faculty of Pharmacy, Vojvode Stepe 450, 11000 Belgrade, Serbia
}

Received 25.03.2019

Accepted 30.03.2019

\begin{abstract}
Octadecyldimethylbenzyl ammonium chloride (OA) was used as a surfactant for the preparation of organokaolin. The natural kaolin (from a plant for production of quartz sand in Rgotina, Serbia) was modified with a surfactant in amount equal to $90 \%$ of the kaolin cation exchange capacity (CEC). FTIR spectroscopy was used for characterization of the new product. FTIR spectra confirmed the presence of OA ions at the kaolin surface. Adsorption of mycotoxins - zearalenone (ZEN) and ochratoxin A (OCHRA) was studied by organokaolin at different amounts of adsorbent and pHs. Results showed that the presence of organic cations in the kaolin structure increased adsorption of both ZEN and OCHRA. Adsorption of the mycotoxins by organokaolin increased with increasing amounts of adsorbent and, at the lowest amount of solids in suspension, adsorption of ZEN and OCHRA was slightly higher at $\mathrm{pH} 7$ and 9.
\end{abstract}

Keywords: mycotoxins; kaolin; surfactants; adsorption.

\section{Introduction}

Mycotoxins are secondary metabolites of different fungi mainly belonging to Fusarium, Aspergillus, and Penicillium species. The most frequently found mycotoxins in agricultural and food systems, include aflatoxins, ochratoxins, patulin, fumonisins, trichothecenes, and zearalenone. Zearalenone - a mycotoxin produced by fungi belonging to the Fusarium family, has attracted particular attention, because of its strong estrogenic activity. The chemical structure of zearalenone (Figure 1a) is similar

\footnotetext{
* Corresponding author: Aleksandra S. Daković,a.dakovic@itnms.ac.rs
} 
to natural estrogens such as $17 \beta$-estradiol and, as a result, it can bind to estrogen receptors, disturbing the hormonal balance and leading to numerous diseases of the reproductive system $[1,2]$.

Ochratoxin A (OCHRA) (Figure 1b), one of the most widespread and hazardous mycotoxins produced by fungi of the genera Aspergillus and Penicillium are commonly present in cereals, grapes, coffee, and cocoa. It is reported that OCHRA has teratogenic, nephrotoxic, genotoxic, carcinogenic and immunotoxic effects. Also, it is suspected that OCHRA can cause Balkan Endemic Nephropathy, a chronic disease of kidneys [3-5].<smiles>COC(C)CCCC(=O)CCC/C=C/c1cc(O)cc(O)c1C(=O)O</smiles>

a)<smiles>CC1Cc2c(Cl)cc(CC(=O)NC(Cc3ccccc3)C(=O)O)c(O)c2C(=O)O1</smiles>

b)

Fig. 1. Chemical structures: a) zearalenone and b) ochratoxin A.

Adsorption is one of the most promising techniques for detoxification of animal feed contaminated with mycotoxins [6,7]. The phyllosilicate clay - montmorillonite and natural zeolites - clinoptilolite and phillipsite, either in the natural or in the surfactantmodified forms are commonly used adsorbents for removal of mycotoxins. Beside montmorillonite, kaolinite and illite, are also layered aluminosilicate minerals, that are widely used in industrial products, such as ceramic, plastic, paint, paper, rubber and cosmetics [8]. Kaolinite modified with surfactants has been used for the removal of different pollutants [9-12].

This study aims to prepare an organo modified kaolin and to investigate if this material will be capable in adsorbing two common mycotoxins -zearalenone and ochratoxin $\mathrm{A}$, under in vitro conditions.

\section{Experimental procedure}

The natural kaolin (KA) was used as a mineral raw material. It was supplied from a plant for production of quartz sand in Rgotina, Serbia and used without pretreatment for production of organokaolin and for subsequent adsorption of zearalenone and ochratoxin A. The XRPD pattern of starting kaolin, presented at Fig. 2., showed, that the main phase is kaolinite mineral (the main intense basal reflection $\left(\mathrm{d}_{001}\right)$ of kaolinite at 7.09 $\AA$ ), with quartz and mica as impurities [13]. 


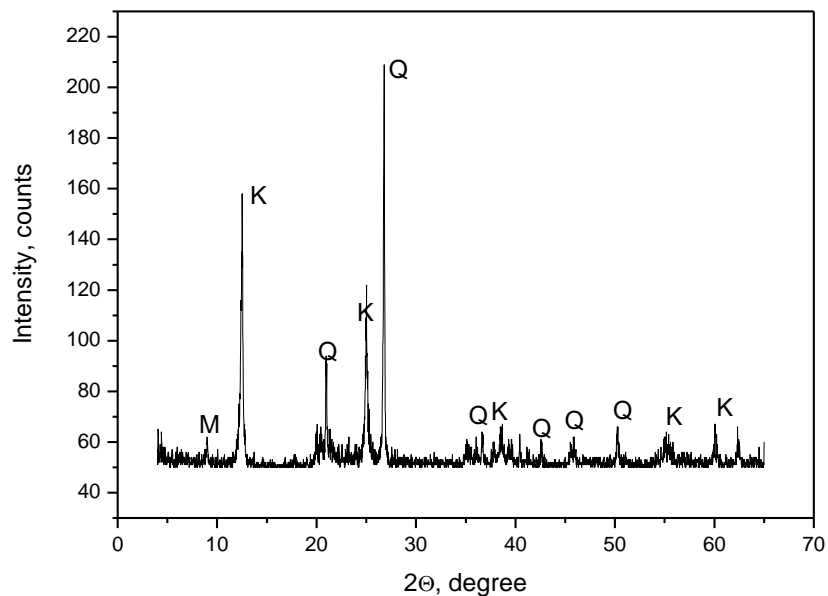

Fig. 2. XRPD pattern of the natural kaolin [13].

The total cation exchange capacity (CEC) of the natural kaolin, determined by methylene blue adsorption method, was 6 meq/100g. The surfactant, octadecyldimethylbenzyl ammonium chloride (OA) was purchased from Sigma Co. The organokaolin was prepared by treatment of the starting kaolin with OA ions in the amount equivalent to $90 \%$ of its CEC. Before modification, the surfactant was dissolved in warm distilled water. Kaolin $(20 \mathrm{~g})$ was then mixed with $100 \mathrm{~mL}$ of the surfactant solution in a mixer at $5000 \mathrm{rpm}$ for $10 \mathrm{~min}$ at $50^{\circ} \mathrm{C}$. The product (OKA) was rinsed with distilled water until $\mathrm{Cl}^{-}$ions were no longer detected and dried at $60^{\circ} \mathrm{C}$.

FTIR spectroscopy was used for characterization of KA and OKA. FTIR analysis was done using a Thermo Scientific iS50 spectrometer with a diamond attenuated total reflectance (ATR) smart accessory at a spectral resolution of $2 \mathrm{~cm}^{-1}$ with 256 scans over a range of $4000-400 \mathrm{~cm}^{-1}$.

Sigma Co supplied zearalenone and ochratoxin A. The effects of adsorbent mass (3.0, $1.5,1.0$ and $0.5 \mathrm{mg} / \mathrm{mL}$ ) on adsorption of ZEN and OCHRA were investigated. Due to the low solubility of most of the mycotoxins in water, the initial concentration $\left(\mathrm{C}_{0}\right)$ of each mycotoxin of $2 \mathrm{mg} / \mathrm{L}$ was used in experiments. The $\mathrm{pH}$ of the buffer solution was adjusted to $\mathrm{pH} 3,7$ and 9 . Suspensions $(\mathrm{V}=10 \mathrm{~mL})$ were shaken at room temperature for $30 \mathrm{~min}$, and non-adsorbed concentrations of mycotoxins were determined by high-performance liquid chromatography (HPLC). The Hitachi HPLC system included a pump (L-7100), autosampler (L-7200) and fluorescence detector was used. Chromatographic separations were carried out on C18 Rexchrom column (Regis $150 \times 4.6 \mathrm{~mm}, 5 \mu \mathrm{m}$ particle size). For both mycotoxins, the mobile phase was acetonitrile: water (60:40) with $1 \%$ acetic acid and was pumped at a flow rate of 1 $\mathrm{mL} / \mathrm{min}$. The fluorescence detection wavelengths were $\lambda \mathrm{ex}=274 \mathrm{~nm}$ and $\lambda \mathrm{em}=465 \mathrm{~nm}$ for ZEN and $\lambda \mathrm{ex}=365 \mathrm{~nm}$ and $\lambda \mathrm{em}=450 \mathrm{~nm}$ for OCHRA. The amounts of ZEN and OCHRA, adsorbed by kaolin and organokaolin were calculated from the difference between the initial and final concentrations of mycotoxins $[14,15]$. 


\section{Results and discussion}

It is well known that the natural form of aluminosilicate minerals is inefficient in binding low polarity molecules, like majority of the mycotoxins. Namely, inorganic cations, present in the interlayers of clays and in the zeolites channels make these minerals hydrophilic and thus, less effective in binding nonpolar organic compounds. Replacement of inorganic cations in minerals with long chain organic cations (surfactants) makes their surfaces hydrophobic and consequently compatible with organic molecules [15-17]. Usually, the amount of loaded surfactant depends on the cation exchange capacity (CEC) of clay minerals or external cation exchange capacity (ECEC) of zeolites [14, 18]. Compared to montmorillonite, kaolinite is a non-swelling clay and possess much lower CEC; thus lower amounts of surfactant are needed for modification of this mineral. The starting material - kaolin was modified with surfactant by cation exchange. Octadecyldimethylbenzyl ammonium ions were added in an amount equal to $90 \%$ of the kaolin CEC value. It was previously reported that modification of kaolin with surfactant did not cause any changes in XRPD patterns (for OKA d $\mathrm{d}_{001}=7.12 \AA$ ) $[13,19]$.

FTIR spectra of kaolin treated with OA ions (Fig. 3) showed absorption bands at 2850 and $2920 \mathrm{~cm}^{-1}$ associated with symmetric and asymmetric stretching vibrations of the $\mathrm{C}-\mathrm{C}$ bond in the alkyl chain respectively. The band at $1470 \mathrm{~cm}^{-1}$ corresponds to bending vibrations of the $\mathrm{CH}_{2}$ group. These bands are characteristic of the surfactants presence at the mineral surface confirming the success of the modification process [20, $21]$.

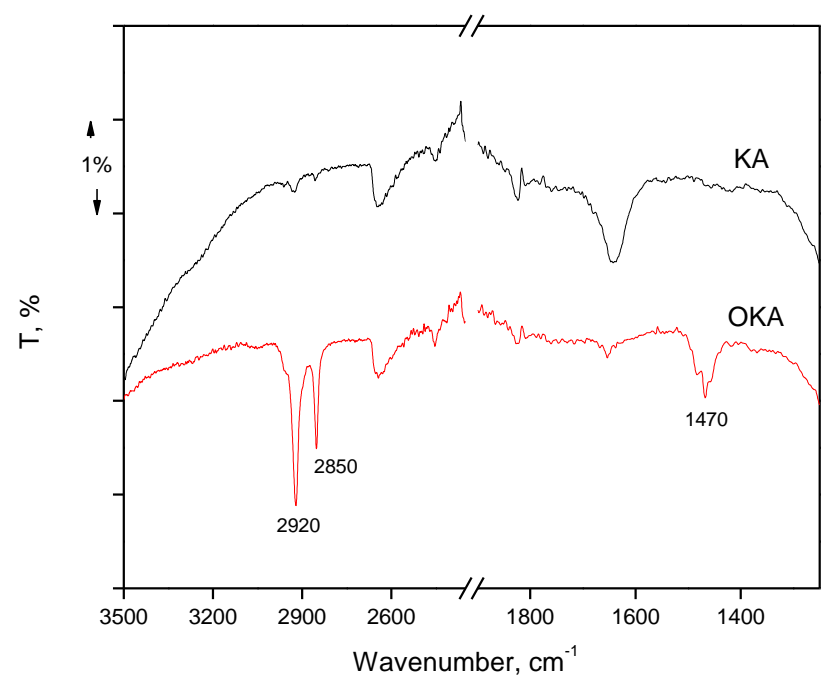

Fig. 3. FTIR spectra of kaolin (KA) and organokaolin (OKA). 
In Table 1, results of the adsorption of ZEN at different amounts of adsorbent in suspension and the initial ZEN concentration of $2 \mathrm{mg} / \mathrm{L}$, at $\mathrm{pH} \mathrm{3,7}$ and 9 are presented. At all three $\mathrm{pH}$ values, ZEN adsorption by modified kaolin increased with increasing amounts of adsorbent in suspension. Preliminary experiments on adsorption of ZEN by the natural kaolin $\left(\mathrm{C}_{0}\right.$ ZEN $=2 \mathrm{mg} / \mathrm{L}$; Csusp $\left.=5 \mathrm{mg} / \mathrm{mL}\right)$ showed low adsorption $-4 \%$ at $\mathrm{pH} \mathrm{3,7 \%}$ at $\mathrm{pH} 7$ and $0 \%$ at $\mathrm{pH}$ 9. Thus, modification of kaolin with organic cations significantly increased ZEN adsorption, and its adsorption was practically independent on $\mathrm{pH}$.

Table 1. Adsorption of ZEN by organokaolin at $\mathrm{pH} 3, \mathrm{pH} 7$ and 9.

\begin{tabular}{lccc}
\hline & \multicolumn{3}{c}{ ZEN adsorption $(\%)$} \\
\cline { 2 - 4 } & $\mathrm{pH} \mathrm{3}$ & $\mathrm{pH} \mathrm{7}$ & $\mathrm{pH} \mathrm{9}$ \\
\hline OKA & & & \\
3.0 & 98 & 99 & 99 \\
1.5 & 95 & 97 & 98 \\
1.0 & 93 & 96 & 97 \\
0.5 & 82 & 91 & 91 \\
\hline
\end{tabular}

Daković et al. (2005), studied the adsorption of ZEN by zeolite - clinoptilolite modified with different amounts of the same organic cation (OA) and reported that presence of an organic cation at the surface of the organozeolite significantly increased the ZEN adsorption, at $\mathrm{pH} \mathrm{3,7}$ and 9. They stated that the degree of hydrophobicity plays a role in the adsorption of this hydrophobic molecule on organozeolites [18]. Results in this paper indicated that organic cations at the kaolin surface are also active sites responsible for ZEN adsorption; even with the lowest amount of adsorbent in suspension $(0.5 \mathrm{mg} / \mathrm{L})$ adsorption of ZEN was still high, suggesting that there are still enough active sites available for adsorption of ZEN.

Adsorption of OCHRA was followed at different amounts of adsorbent in suspension at the constant initial concentration of OCHRA of $2 \mathrm{mg} / \mathrm{L}$ at three $\mathrm{pH}$ values. Obtained results are presented in Table 2.

Table 2. Adsorption of OCHRA by organokaolin at pH 3, pH 7 and 9.

\begin{tabular}{lccc}
\hline & \multicolumn{3}{c}{ ZEN adsorption (\%) } \\
\cline { 2 - 4 } & $\mathrm{pH} \mathrm{3}$ & $\mathrm{pH} \mathrm{7}$ & $\mathrm{pH} \mathrm{9}$ \\
\hline OKA & & & \\
$(\mathrm{mg} / \mathrm{mL})$ & & 100 & 100 \\
3.0 & 97 & 99 & 100 \\
1.5 & 92 & 99 & 88 \\
1.0 & 87 & 78 & 88 \\
0.5 & 71 & & \\
\hline
\end{tabular}

As can be seen from Table 2, adsorption of OCHRA by the organokaolin increased with increasing amounts of adsorbent in suspension. As in the case of ZEN, OCHRA is low polarity molecule, and in the preliminary experiment $\left(\mathrm{C}_{0}\right.$ OCHRA $=2$ $\mathrm{mg} / \mathrm{L}$; Csusp $=5 \mathrm{mg} / \mathrm{mL}$ ) very low adsorption of OCHRA was observed by the natural kaolin $-6 \%$ at $\mathrm{pH} 3$ and $0 \%$ at $\mathrm{pH} 7$ and 9. Thus, organic cations at the kaolin surface 
are the most probably responsible for adsorption. For the lower amounts of the solid phase in suspension, slightly higher adsorption of OCHRA was noticed at $\mathrm{pH} 7$ and 9 . Daković et al. (2003) demonstrated an efficient adsorbent for OCHRA obtained by modification of zeolite - clinoptilolite with the same long chain organic cation (OA) and similarly noticed, a significant increment in adsorption of OCHRA by organozeolites, while adsorption of OCHRA was low on the natural material [22]. Based on the preliminary results presented in this paper, kaolin modified with long chain organic cations may be effective for adsorption of mycotoxins - ZEN and OCHRA.

\section{Conclusion}

Natural kaolin was modified with a long chain organic cation octadecydimethilbenzyl ammonium (OA) and was used for adsorption of mycotoxins zearalenone (ZEN) and ochratoxin A (OCHRA) from the buffer solution. The effect of the amount of adsorbent and $\mathrm{pH}$ of the solution on ZEN and OCHRA adsorption was investigated. For both ZEN and OCHRA, adsorption increased with increasing the amount of solid phase in suspension confirming that OA ions are the active sites that are responsible for their adsorption. Adsorption of ZEN and OCHRA was slightly higher at neutral and alkaline $\mathrm{pHs}$.

\section{Acknowledgments}

This work was performed under the projects TR 34013 and ON 172018 supported by the Ministry of Education, Science and Technological Development of the Republic of Serbia

\section{References}

[1] Y. Luo, X. Liu, J. Li: Food Control, 89 (2018) 123-132.

[2] A. Rogowska, P. Pomastowski, G. Sagandykova, B. Buszewski: Toxicon, 162 (2019) 46-56.

[3] T. P. Lee, B. Saad, E. P. Ng, B. Salleh: J Chromatog A, 1237 (2012) 46-54.

[4] S. Amézqueta, E. González-peñas, M. Murillo-arbizu, A. López, D. Cerain: Food Control, 20 (2009) 326-333.

[5] I. Var, B. Kabak, Z. Erginkaya: Food control, 19 (2008) 592-598.

[6] P. Vila-Donat, S. Marín, V. Sanchis, A.J. Ramos: Food Chem Toxicol, 114 (2018) 246-259.

[7] A. Daković, M. Kragović,G.E. Rottinghaus, Ž. Sekulić, S. Milićević, S.K. Milonjić, S. Zarić: Colloids Surf B: Biointerfaces, 76 (2010) 272-278.

[8] L. Liu, F. Min, J. Chen, F. Lu, L. Shen: Appl Surf Sci, 470 (2019) 27-35.

[9] J. Wan, L. Wang, X. Lu, Y. Lin, S. Zhang: J Hazard Mater, 196 (2011) 79-85.

[10] R. Zafar, J.S. Watson: Chem Geol, 471 (2017) 111-118.

[11] N.S. Mirbagheri, S. Sabbaghi: Microporous Mesoporous Mater, 259 (2018) 134141.

[12] X. Zhang, S. Lin, Z. Chen, M. Megharaj, R. Naidu: Water Res, 45 (2011) 34813488.

[13] V. Rakić, N. Rajic, A. Daković, A. Auroux: Microporous Mesoporous Mater, 166 (2013) 185-194.

[14] M. Marković, A. Daković, G.E. Rottinghaus, M. Kragović, A. Petrović, D. Krajišnik, J. Milić, M. Mercurio, B. De Gennaro: Colloids Surf B: Biointerfaces, 151 (2017) 324-332. 
[15] M. Marković, A. Daković, G.E. Rottinghaus, A. Petrović, M. Kragović, D. Krajišnik, J. Milić: Colloids and Surfaces A, 529 (2017) 7-17.

[16] R.R. Santos, S. Vermeulen, A. Haritova, J. Fink-Gremmels: Food Additives and Contaminants, 28 (2011) 1578-1589.

[17] [17] J.F. Alberts, M. Lilly, J.P. Rheeder, H-M. Burger, G.S. Shephard, W.C.A. Gelderblom: Food Control, 73 (2017) 101-109.

[18] [18] A. Daković, M. Tomašević-Čanović, V. Dondur, G.E. Rottinghaus, V. Medaković, S. Zarić: Colloids Surf B: Biointerfaces, 46 (2005) 20-25.

[19] [19] C. del Hoyo, C. Dorado, M. S. Rodríguez-Cru, M. J. Sánchez-Martín: J Therm Anal Cal, 94 (2008) 227-234.

[20] [20]Z. Li, L. Gallus, Colloids and Surfaces A: Physicochem Eng Aspects, 264 (2005) 61-67.

[21] [21] M. Majdan, S. Pikus, Z. Rzączyńska, M. Iwan, O. Maryuk, R. Kwiatkowski, H. Skrzypek: J Mol Struct, 791 (2006) 53-60.

[22] [22] A. Daković, M. Tomašević-Čanović, G. Rottinghaus, V. Dondur, Z. Mašić: Colloids Surf. B: Biointerfaces, 30 (2003) 157-165.

\section{(c) (i) Creative Commons License}

This work is licensed under a Creative Commons Attribution 4.0 International License. 